Tal como podemos verificar pela análise do GRÁFICO II, nem todos os Centros de Estágio se localizam no distrito de Viseu.

Neste ano lectivo disponibilizaram centros de Estágio organizações económicas e sociais localizadas nos distritos de Aveiro (18,06\%), Coimbra (1,39\%), Guarda $(5,56 \%)$, Leiria $(1,39 \%)$, Porto $(8,33 \%)$ Lisboa $(1,39 \%)$ e Viseu $(63,89 \%)$.

São sobretudo empresas industriais que colaboram com o I.U.D.P.S., para proporcionarem aos estagiários contacto com a realidade profissional, onde futuramente se irão inserir.

O estágio anual termina com a apresentação pública, perante um júri, do relatório elaborado pelo aluno, em função do trabalho realizado.

\title{
7. ASSOCIAÇÃO DE APOIO AO INSTITUTO UNIVERSITÁRIO DE DESENVOLVIMENTO E PROMOÇÃO SOCIAL
}

A Associação de Apoio ao Instituto Universitário de Desenvolvimento e Promoção Social, para além de continuar a dar apoio às actividades desenvolvidas no âmbito do Instituto Universitário de Desenvolvimento e Promoção social, nomeadamente na organização do processo de estágios, realizou outras actividades durante o ano lectivo 1994/95, das quais se destacam:

- Estudo de caracterização socioeconómica da aldeia de Freixo, pertencente ao concelho de Mortágua;

- Estudo de caracterização socioeconómica da aldeia de Almacinha, pertencente ao concelho de Mortágua;

- Estudo de caracterização socioeconómica do distrito de Viseu, em colaboração com o Governo Civil.

Esta Associação continua a desenvolver acções no sentido de satisfazer as necessidades dos sócios e de outras empresas, autarquias e instituições privadas de solidariedade social. Procura promover o desenvolvimento, de forma articulada com os diferentes agentes económicos e sociais.

Graça Ferreira 